of thirty months as hitherto, and entry is still limited to part-time students. The Ministry of Education Science Scholarships examinations in engineering will continue to be used for the purpose of making the awards, but the conditions for these have also been amended. Candidates will be required to reach a certain minimum standard in the two qualifying papers of mathematics and applied mechanics, and will also be required to take three scholarship papers, chosen from a number of alternatives. Workshop technology is introduced for the first time as one of these subjects. The entries for the Whitworth Senier Scholarships have, in the past, been governed by the same conditions as for the Whitworth Scholarships. Many university students could not qualify, however, because of the practical training conditions; this requirement has now been omitted, but a successful candidate will have to spend at least one year in a works on taking up a Senior Scholarship. No formal examination will be held, but a candidate must submit a thesis on one of a number of specified subjects.

\section{Collection of Czechoslovak Chemical Communications}

FOUNDED in 1929 for the purpose of publishing in French or English the results of researches conducted by Czechoslovak chemists, the Collection of Czechoslovak Chemical Communications, which ceased pub. lication in 1939, has now been resumed under the same editorial direction of Profs. J. Heyrovsky and E. Votočk. The first issue for 1947 contains an appreciation of the scientific work of Prof. Antonin Simek, who was executed by the Germans during the War (see Nature, 152, 69 ; 1943). About half this issue is taken up with the recent polarographic researches of Heyrovský and his co-workers, who have studied certain phenomena at the dropping (and streaming) mercury cathode both polarographically and oscillographically. These open up an important new field in the study of electrode interfaces. From the laboratory of Prof. Votocek there is a paper on the synthesis of the remaining monomethyl-azulene. The authors, F. Sorm and J. Fajkor, started with cis-and trans-cyclopentane-dipropionic$(1,2)$-acids, and by a series of interesting steps arrived at the trinitrobenzene compound of 6-methylazulene. This was decomposed chromatographically over an aluminium hydroxide column. Finally, methyl-azulene was crystallized as a purple-blue solid, m.p. $83^{\circ}$ C. Another contribution to organic chemistry is by Dr. R. Lukes, who describes N-methyl-1.2.5.6.-tetrahydropyridine. The subscription for the journal has been raised to $£ 2$ or 400 Czechoslovak erowns.

\section{Royal Institute of Chemistry: Anniversary Meeting}

THE sixty-ninth annual general meeting of the Royal Institute of Chemistry was held on April 18. In presenting the report of the Council for 1946, the president, Mr. G. Roche Lynch, referred to some of the principal developments in the work of the Institute. Closer contact with the four Dominion chemical institutes had been established through a meeting with their representatives which was held in London last June. The first edition of a "Directory of Independent Consultants in Chemistry and Related Subjects" was issued during the year. Highly successful courses in "Oils and Fats" and "Spectroscopy", arranged at the University of Liverpool by the
Liverpool and North Western Section of the ${ }^{*}$ Institute, represented the first of the series of courses, conferences and symposia to be held under the auspices of the Institute as such. Through the generosity of Dr. David Spence, a series of Henderson Memorial Lectures had been established as a tribute to the memory of the late Prof. G. G. Henderson, a past president of the Institute; and the first lecture in this series was delivered by Sir Ian Heilbron. By agreement between the Ministry of Education and the Institute, the scheme for national certificates has been amended so as to provide separate certificates in chemistry and in applied chemistry. During 1946, the membership of the Institute (fellows and associates) passed the 10,000 mark. Mr. G. Roche Lynch was elected president for 1947-48.

\section{"Specpure" and "H.S." Elements and Chemicals}

Certarn metals and chemicals of the very highest purity for spectrographic work were first supplied on a small scale by Messrs. Adam Hilger, Ltd., in 1923, and their "H.S." and "Specpure" chemicals are now well known. With increased demand for more substances and greater quantities, it has been found desirable to transfer the preparation of these carefully standardized substances to Messrs. Johnson, Matthey and Co. The range of available chemicals, to be marketed as "H.S.", "Specpure" or "Matthey" standards, has been considerably extended; some sixty-eight elements are listed, either as metals, oxides or salts, in Johnson and Matthey's latest catalogue. They are all of the highest possible purity, and their manufacture is controlled spectrographically.

\section{International Geological Congress, 1948}

The 18th Session of the International Geological Congress, originally planned for 1940 and postponed on the outbreak of war, is to be held in Great Britain in 1948, on the invitation of the Geological Society of London. A third circular containing preliminary arrangements for the session has been issued. Meetings will take place in London during August 25-September 1, 1948, and the following subjects have been provisionally listed for discussion: (1) Problems of Geochemistry; (2) Metasomatic Processes in Metamorphism; (3) Rhythm in Sedimentation ; (4) Geological Results of Applied Geophysios ; (5) Geology of Iron-Ore Deposits ; (6) Geology of Petroleum; (7) Geology, Paragenesis and Reserves of the Ores of Lead and Zinc ; (8) Geology of Sea and Ocean Floors; (9) Pliocene-Pleistocene Boundary; (10) Faunal and Floral Facies and Zonal Correlation; (11) Correlation of Continental Vertebrate-bearing Rocks ; (12) Earth Movements and Organic Evolution. Geological excursions covering most of the British Isles, which are planned to take place between August 7 and September 18, form part of the Congress programme. They include sixteen long excursions (7-16 days) before the meetings in London, and sixteen of similar length after the meetings. There will also be daily excursions, centred on London, between August 22 and September 3. Sir Thomas Holland is president of the General Organising Committee and president-designate of the Congress. The general secretaries are Mr. A. J. Butler and Dr. L. Hawkes, and the treasurer is Mr. F. N. Asheroft. All communications should be addressed to the General Secretaries, XVIII Session International Geological Congress, Geological Survey and Museum, Exhibition Road, London, S.W.7. 